\title{
Detection of root canals in historical population from Radom (Poland)
}

\author{
A. Przesmycka1', J. Tomczyk², A. Pogorzelska³, P. Regulski, ${ }^{3}$, K. Szopiński \\ ${ }^{1}$ Department of Anthropology, Jagiellonian University, Krakow, Poland \\ 2Institute of Biological Sciences, Cardinal Stefan Wyszynski University, Warsaw, Poland \\ ${ }^{3}$ Dentomaxillofacial Radiology Department, Medical University of Warsaw, Poland \\ ${ }^{4}$ Centre of Digital Science and Technology, Cardinal Stefan Wyszynski University, Warsaw, Poland
}

[Received: 21 November 2019; Accepted: 3 January 2019]

Background: The aim of this study was to analyse the number of root canals in maxillary first premolars, first molars and mandibular first molar teeth from an $18^{\text {th }}$ to $19^{\text {th }}$ century Radom (Poland) population, and then assess whether the diversity of root canals has fluctuated for about two hundred years.

Materials and methods: A total of 139 human permanent teeth were analysed by cone beam computed tomography in three projections. The types of root canal systems were classified in each tooth root separately.

Results: In one-rooted maxillary premolars, two canals occurred most often (53\%). In two-rooted majority buccal (91\%) and every palatal roots there is one canal. All three-rooted maxillary premolars have one root canal. In two-rooted first maxillary molars, fused roots have two canals. All mesiobuccal roots presented type 2-1 canal configurations. In three-rooted maxillary first molars in the mesiobuccal roots the most common root canal type is 2-1 (72\%). A second mesiobuccal canal occurred in $86 \%$. The distobuccal and palatal roots presented one canal in all cases. First mandibular molars occurred in two-rooted form in 98\%. In mesial roots, two root canals predominated (59\%). Most distal root (66\%) had one canal. In three-rooted teeth one root canal was the most frequent finding.

Conclusions: Knowledge about the variation in root canals is important in studies of past populations. This evidence may be important in relation to assessing the variability of human populations. The analysis carried out show the cohesion between the historical population of Radom and other groups from modern Poland. (Folia Morphol 2019; 78, 4: 853-861)

Key words: root canal systems, historical teeth, cone beam computed tomography, Radom

\section{INTRODUCTION}

In endodontics the anatomical complexity of external and internal tooth roots in human permanent dentition has been studied, identified and a naming system was formulated [21, 28]. Accurate knowledge of the variability, the number and the morphology of root canal systems is essential during endodontic treatment [13]. However, such studies are usually restricted to studies of contemporary populations $[3,50]$. To our knowledge studies of internal morphology in historical populations' dentition, especially described root canal systems, are very rare and only occasionally discussed [11, 35, 36]. One of the reasons is the often poor preservation of archaeologically derived human remains due to diagenetic and taphonomic changes that occur to bones and teeth 
after the death of an individual [53]. However, those analyses can provide a vital source of information for bioarchaeological research [33]. Knowledge about the diversity of root canal systems let to characterise populations' variability.

The causes of root canals diversity observed among human populations are still discussed. Many studies prove that the variation in root canal systems is connected with the different "racial" populations. There are several dental differences between populations around the world that are manifested in the internal morphology of teeth. The relative prevalence of some traits could characterise and differentiate ethnical human groups $[14,41]$. And, these analyses, from the point of bioarchaeological studies, seems to be the most interesting. However, age at individual, dental wear or some diseases (such as taurodontism dentinal dysplasia, thalassemia and irradiation during odontogenesis) also cause changes in the development of root canals $[20,39]$.

Taking into account the diversity of root canals, it seems that in bioarchaeological research attention should be focused on some types of teeth. Maxillary first premolars exhibit variable root canal morphology and pulp cavity configurations. The three-canalled form of these teeth resembles the adjacent molars and they are therefore sometimes called small molars [2]. Similarly, important to the examinations may be maxillary first molars. They are one of the most complex teeth on the strength of their multidimensional external and internal morphology $[27,49]$. The presence and anatomic configuration of a second mesiobuccal root canal, heterogeneous due to sex and age, in these teeth has generated more clinical investigations and research than any root in the mouth $[9,46]$. Another type of tooth with a number of anatomical variations is mandibular first molars $[1,5]$. Due to the high carries susceptibility and diversity of root canal numbers, this is often the most heavily restored tooth in adult dentition. Moreover, the mesiobuccal canal tends to manifest the greatest degree of curvature $[4,28]$.

The purpose of this study was to investigate morphology, possible variability or permanence of root canals in the $18^{\text {th }}-19^{\text {th }}$ century teeth belonging to historical population from Radom (Poland). Lack of research on this topic in historical populations prompted us to carry out such analyses. The question is whether the morphology of root canals of selected teeth in this historical population for about 200 years has fluctuated in relation to the morphology of root

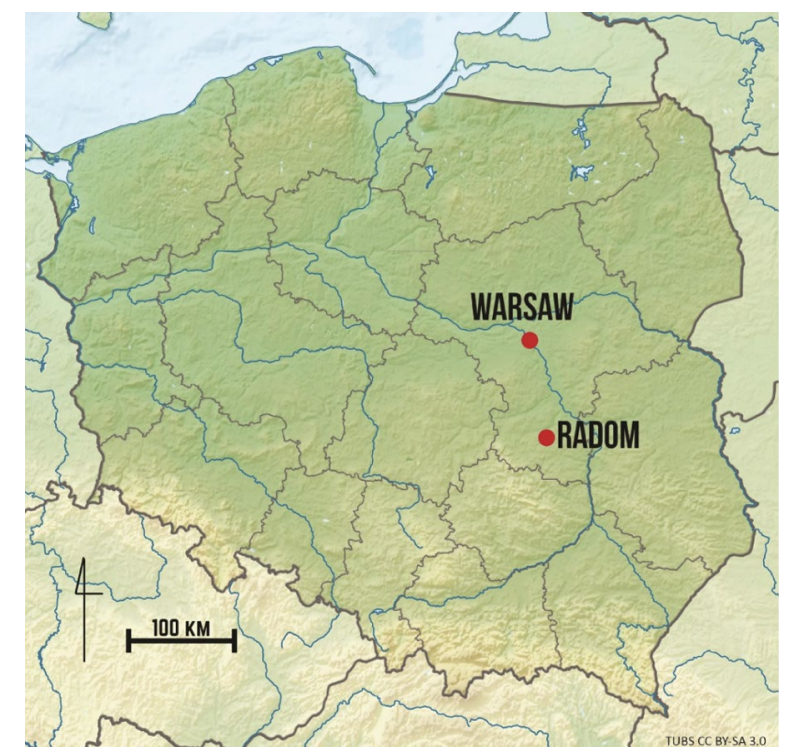

Figure 1. Location map of the study area.

canal systems in the teeth of contemporary populations from Poland.

\section{MATERIALS AND METHODS}

The dental material came from the Radom cemetery dated within the $18^{\text {th }}-19^{\text {th }}$ century. According to historical information, the first urban municipal cemetery was founded at the stronghold in 1791, but due to the lack of space, a new cemetery was established in 1811 at another location. Consequent$l y$, the municipal cemetery at the stronghold was abandoned and forgotten [34,54]. This means that all examined human remains were buried within a 20 year timeframe (Fig. 1).

The Radom Cemetery collection curated at the Department of Human Ecology at Cardinal Stefan Wyszynski University (Warsaw, Poland).

A total of 34 individuals of both sexes were examined. We do not separated material due to the demographic structure to avoid small sample sizes making the interpretation of the results difficult. Consideration was limited to first maxillary premolars $(n=41)$, first maxillary molars $(n=43)$ and first mandibular molars $(n=55)$. A total of 139 teeth were examined (Table 1).

An exhaustive selection of teeth was carried out. Only the well-preserved teeth, which could be verified by crown and root morphology, were included in the study. It is known fact that the dental wear can affect the pulp chamber shape or the course of root 
Table 1. Total number of selected teeth and their roots used in this study

\begin{tabular}{|c|c|c|c|c|c|}
\hline No. teeth* & No. individuals & No. teeth & No. roots & Root type & No. of roots \\
\hline \multirow{6}{*}{14,24} & \multirow{6}{*}{41} & \multirow{6}{*}{41} & 1 & Single (S) & 17 \\
\hline & & & 2 & Buccal (B) & 22 \\
\hline & & & & Palatal (PAL) & 22 \\
\hline & & & 3 & Mesiobuccal (MB) & 2 \\
\hline & & & & Distobuccal (DB) & 2 \\
\hline & & & & Palatal (PAL) & 2 \\
\hline \multirow{5}{*}{16,26} & \multirow{5}{*}{43} & \multirow{5}{*}{41} & 2 & Mesiobuccal (MB) & 4 \\
\hline & & & & $\begin{array}{c}\text { Distobuccal+Palatal } \\
\text { (DB+PAL) }\end{array}$ & 4 \\
\hline & & & 3 & Mesiobuccal (MB) & 39 \\
\hline & & & & Distobuccal (DB) & 39 \\
\hline & & & & Palatal (PAL) & 38 \\
\hline \multirow{5}{*}{36,46} & \multirow{5}{*}{55} & \multirow{5}{*}{55} & 2 & Mesial (M) & 54 \\
\hline & & & & Distal (D) & 53 \\
\hline & & & 3 & Mesial (M) & 1 \\
\hline & & & & Distobuccal (DB) & 1 \\
\hline & & & & Distolingual (DL) & 1 \\
\hline
\end{tabular}

*Numeration according to Fédération Dentaire Internationale (FDI)

canals $[13,15]$. Therefore, the scores of mechanical dental attrition of posterior teeth were based on the scale proposed by Smith [45] (wear scoring system for premolars) and Scott [40] (wear scoring system for molars). These scales are commonly used in bioarchaeological studies. The three classes of dental wear were separated according to the degree of dentin exposure:

- wear facets that are invisible or very small (Smith's scale, No. 1-2; Scott's scale, No. 1);

- wear facets that are moderately advanced (Smith's scale, No. 3-4; Scott's scale, No. 2-5);

- wear facets that are highly advanced (Smith's scale, No. 5-8; Scott's scale, No. 6-10).

Teeth with highly advanced dental attrition were excluded from further analysis.

We chose only permanent teeth with completely developed roots without any traces of damage or some diseases (e.g., post-mortem damage, caries lesions or taurodontism dentinal dysplasia). Root fractures or cracks were ruled out by further studies. We examined the teeth embedded in the alveolar bone. All the first maxillary premolars, first molars and first mandibular molars that fulfilled this requirement included the study sample. The analysed sample may seem too small; however, it should be kept in mind that just a small part of unique historical dental material have remained to present day. Moreover, the available studies of teeth root canal systems in historical populations were based on a similar sample size [11, 35]. According to Turner et al. [51] we assume a separate root as has one-quarter to one-third of the total root length independent of the others. An individual root canal was defined as a separate orifice found on the floor of the pulp chamber [30].

Cone-beam computed tomography (CBCT) analysis was performed separately for each root, and all visible canals were marked. The prepared samples were placed onto the bite plane of a Scanora 3Dx (Sorodex, Finland), with the following parameters for each exposition as: $90 \mathrm{kV}, 10 \mathrm{~mA}$, field of view (FOV) $50 \times 100 \mathrm{~mm}$ (for mandible and maxilla analysed together) and $80 \times 165 \mathrm{~mm}$ (for mandible or maxilla analysed separately), voxel size $0.2 \mathrm{~mm}$ and $0.15 \mathrm{~mm}$ and dose area product $442 \mathrm{mGy} / \mathrm{cm}^{2}$ and $1333 \mathrm{mGy} / \mathrm{cm}^{2}$, respectively, for each FOV. Scans were taken in accordance with the manufacturer's recommended protocol.

The selected method is non-invasive and does not damage the historical material. Images were examined with the OnDemand3D Application (Cybermed, Daejeon, Korea) and were assessed on medical display (14-bit NEC MDview 243). The following features were analysed: the number of roots, the number of 
Table 2. Root canal configurations in each type of root in selected material from Radom

\begin{tabular}{|c|c|c|c|c|c|c|c|c|c|c|}
\hline No. teeth* & No. roots & $\begin{array}{l}\text { Type of } \\
\text { canal }\end{array}$ & $\begin{array}{l}\text { No. of } \\
\text { roots }\end{array}$ & 1 & $2-1$ & $1-2-1$ & 2 & $1-2$ & $2-1-2$ & $1-2-1-2$ \\
\hline \multirow[t]{6}{*}{14,24} & 1 & $S$ & 17 & $2(12 \%)$ & $5(29 \%)$ & - & $9(53 \%)$ & - & - & $1(6 \%)$ \\
\hline & 2 & BUC & 22 & 20 (91\%) & - & - & - & $2(9 \%)$ & - & - \\
\hline & & PAL & 22 & $22(100 \%)$ & - & - & - & - & - & - \\
\hline & 3 & $\mathrm{MB}$ & 2 & $2(100 \%)$ & - & - & - & - & - & - \\
\hline & & $\mathrm{DB}$ & 2 & $2(100 \%)$ & - & - & - & - & - & - \\
\hline & & PAL & 2 & $2(100 \%)$ & - & - & - & - & - & - \\
\hline \multirow[t]{5}{*}{16,26} & 2 & MB & 4 & - & $4(100 \%)$ & - & - & - & - & - \\
\hline & & $\mathrm{DB}+\mathrm{PAL}$ & 4 & - & - & - & $4(100 \%)$ & - & - & - \\
\hline & 3 & MB & 39 & $5(13 \%)$ & 28 (72\%) & - & $4(10 \%)$ & - & $2(5 \%)$ & - \\
\hline & & $\mathrm{DB}$ & 39 & $39(100 \%)$ & - & - & & - & - & - \\
\hline & & PAL & 38 & $38(100 \%)$ & - & - & & - & - & - \\
\hline \multirow[t]{5}{*}{36,46} & 2 & $\mathrm{M}$ & 54 & $1(2 \%)$ & 21 (39\%) & - & $32(59 \%)$ & - & - & - \\
\hline & & $D$ & 53 & $35(66 \%)$ & $9(17 \%)$ & $5(9 \%)$ & $3(6 \%)$ & $1(2 \%)$ & - & - \\
\hline & 3 & $\mathrm{M}$ & 1 & $1(100 \%)$ & - & - & - & - & - & - \\
\hline & & DB & 1 & $1(100 \%)$ & - & - & - & - & - & - \\
\hline & & $\mathrm{DL}$ & 1 & $1(100 \%)$ & - & - & - & - & - & - \\
\hline
\end{tabular}

*Numeration according to Fédération Dentaire Internationale (FDI); abbreviations — see Table 1

root canals and the canal configuration. The presence of root canal systems was diagnosed in three projections: coronal, sagittal and axial scans to facilitate the interpretation. The type of root canal systems in the Radom group were classified in each tooth root separately. All experimental procedures in this research were performed in the Dentomaxillofacial Radiology Department of the Medical University in Warsaw.

All scans were evaluated by two independent researchers (AP, PR). Any disagreement was discussed until a consensus was reached. To compare the results, observations of 30 teeth (10 one-rooted teeth, 10 two-rooted teeth, and 10 three-rooted teeth) were carried out. Reliability observations between the two investigators were assessed with the Spearman's rank correlation coefficient. Differences with $p \leq 0.05$ were considered statistically significant. Statistical analyses were performed using the $\mathrm{R}$ Project for Statistical Computing [37].

\section{RESULTS}

A total of 34 CBCT images in different projection of maxillary first premolars, first molars and mandibular first molars were analysed. The number of roots, root canals and the type of root canal configurations were evaluated (Table 2).
Among 41 maxillary first premolars, 41\% (17/41) had one root, 54\% (22/41) had two roots and 5\% $(2 / 41)$ had three roots. The number of canals ranged from one to three in different variants. The incidence of one canal in the present study in one-rooted maxillary premolars was $12 \%(2 / 17)$, two canals joined to one was $29 \%$ (5/17), two canals was $53 \%$ (9/17) and type 1-2-1-2 was 6\% (1/17). In two-rooted maxillary first premolars, majority buccal roots (91\%) and all palatal roots had a one root canal. A similar situation was observed in three-rooted maxillary first premolars.

In first maxillary molars, two-rooted teeth constituted $9 \%$ (4/43), whereas three-rooted constituted $91 \%(39 / 43)$ of 43 teeth. In two-rooted teeth, all masiobuccal roots present type 2-1 canal configurations, while fused roots ( $D B+P A L)$ are characterised by two canals. In three-rooted maxillary first molars in the mesiobuccal root, the most common root canal configuration is type 2-1 (72\%). In the distobuccal and palatal roots, one canal occurred in all cases.

Fifty-five mandibular first molars occurred in twoand three-rooted form (98\%, 54/55 and 2\%, 1/55, respectively). The mesial root in two-rooted form showed great variability in morphological diversity, the most common types of canal configurations were two and two joined into one canal (59\%, 32/54 and 


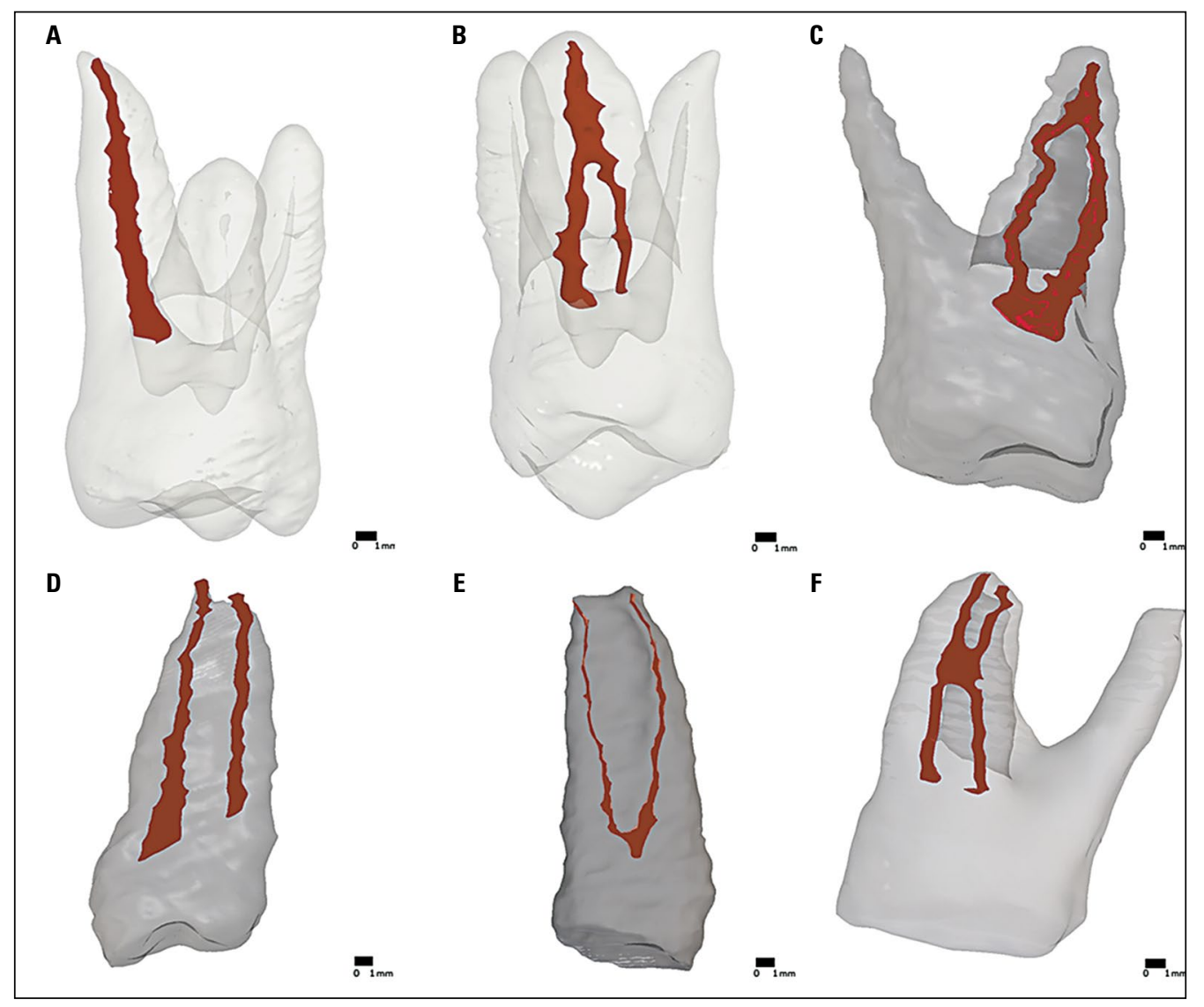

Figure 2. Examples of several types of root canal configurations; A. Type 1; B. Type 2-1; C. Type 1-2-1; D. Type 2; E. Type 1-2; F. Type 2-1-2.

$39 \%, 21 / 54$, respectively). The distal root was characterised mostly by one root canal (66\%). Each root from three-rooted mandibular first molars depicted one root canal. Examples of the observed types of root canals are presented in Figure 2 .

\section{DISCUSSION}

There is a wide range of variation depicted in the literature with respect to frequency of occurrence of the number of roots and root canals [13,28]. In the case of anatomical variations' occurrence, several differentiating factors such as sex $[3,22]$ and geography $[5,7]$ play a role. Morphological dental traits are also slightly affected by environmental factors [42]. Teeth root canals are responsive to changes over the years due to physiological or pathological incidents, such as natural physiological ageing, periodontal disease, occlusal trauma or carious lesions [19, 23]. It has been suggested that the configurations and number of root canals are predominantly determined by the physiological deposition of secondary dentine contributing to a reduction of the pulp chamber size and root canal diameter [15]. Usually in young individuals roots in teeth have single, large canal. With age, deposition of secondary dentine leads to the origination of compartments. This often evokes wide differentiation of the root canal system resulting in the development of separate canals and transverse connecting systems. However, the rate of progress of secondary dentine deposition differentiating the canal system is variable $[33,48]$. Age changes in canal morphology has not been commonly studied in detail and information are unsatisfactory $[15,31]$. They have limitations, including small sample sizes [18, 29], limited groups of teeth [31], or a restricted methodology such as identification of extra root canals during root canal treatment or using periapical radiographs [48]. Even when combining the available data, it is not possible to gain an overall understanding of the changes within the root canal system configuration over time, because many groups of teeth not been studied using $\mathrm{CBCT}$ technology. Another limitation which makes 
Table 3. The comparison of morphology of Radom $\left(18^{\text {th }}-19^{\text {th }}\right)$ teeth root canals and other Poland contemporary groups

\begin{tabular}{|c|c|c|c|c|c|}
\hline & \multicolumn{2}{|c|}{ Radom $18^{\text {th }}-19^{\text {th }}$} & \multirow{2}{*}{$\begin{array}{c}\text { North-western Poland } \\
\text { (modern) }\end{array}$} & \multirow{2}{*}{$\begin{array}{c}\text { South-eastern Poland } \\
\text { (modern) }\end{array}$} & \multirow{2}{*}{$\begin{array}{c}\begin{array}{c}\text { Central Poland } \\
\text { (modern) }\end{array} \\
16,26\end{array}$} \\
\hline No. teeth* & 14,24 & 16,26 & & & \\
\hline No. teeth & 41 & 43 & 142 & 55 & 185 \\
\hline Method of visualisation used & СВCT & СВCT & Radiography & Radiography & СВСТ \\
\hline \multirow[t]{3}{*}{ No. roots (\%) } & $1: 41 \%$ & & $1: 16 \%$ & Lack of information & \\
\hline & $2: 54 \%$ & $2: 9 \%$ & $2: 75 \%$ & & \\
\hline & $3: 5 \%$ & 3: $91 \%$ & 3: $9 \%$ & & $3: 100 \%$ \\
\hline One canal (\%) & $7 \%$ & & $2 \%$ & & \\
\hline Two canals (\%) & $88 \%$ & & $89 \%$ & $91 \%$ & \\
\hline Three canals (\%) & $5 \%$ & $14 \%$ & $9 \%$ & $9 \%$ & $40 \%$ \\
\hline Four canals $(\%)$ & & $86 \%$ & & & $60 \%$ \\
\hline References & Curr & arch & Lipski et al., 2005 & Różyło et al., 2008 & Olczak and Pawlicka, 2017 \\
\hline
\end{tabular}

*Numeration according to Fédération Dentaire Internationale (FDI); CBCT — cone-beam computed tomography

a global conclusion more difficult is the fact that most of the studies arise from different research groups using different population backgrounds. Thus, the age-related changes in root canal anatomy remains underexplored [26]. More detailed examination using a more precise method to visualise the root canal system is necessary to make a tough conclusion about these changes [33].

Furthermore another factor affecting the variability of root canals is ethnicity [6, 22]. It is well-known that root and especially canal morphology differ greatly between populations, within populations and even within the same individuals [3,33]. Therefore, variations in the shape and number of root canals in populations appear to be genetically determined [24]. In endodontics, a lack of comprehensive knowledge about the anatomy of root canal systems might contribute to treatment failure. However, in bioarchaeological research, thorough knowledge about the inner morphology of tooth roots may be helpful in tracing the ethnic origin of the populations [2]. Due to these possibilities and lack of anthropological studies, we can only call for further research on this topic.

According to current data, the greatest variability and complexity regarding the intricate anatomic configuration of root canal systems is exhibited by maxillary first premolars and maxillary and mandibular first molars [1, 2, 12]. Unfortunately, there are no published reports on the variability of root canals in these teeth in archaeological material. It means that the sample from Radom is archaeologically the first material from Poland analysed in the context of historical tooth root canal system morphology. For this reason, several contemporary studies from Poland have been selected as comparison material (Table 3).

Usually, maxillary first premolars have two roots and in most cases two canals (73-95\%), although teeth with one or three root canals (with one canal in each root) do often exist (8-26\% and 0-6\%, respectively). According to different authors, three canals occurred between 0.5 and $7.5 \%$ of the time $[2,47]$. In our study, the most common type of maxillary first premolar is the two-rooted form (54\%). One-rooted type occurred with less frequency (41\%). These findings correspond with the endodontic study regarding the north-western Poland groups (75\% and 16\%, respectively) [25]. The lower number of teeth from Radom caused the prevalence of variation of canal roots to be lower than in the case of studies from contemporary Poland. The numbers of root canals in the first premolars of the maxilla from Radom ranged from one to three. A majority of them (88\%) had two root canals. Similar prevalence of the occurrence of two canals was noted in the study from north-western and south-eastern Poland ( $89 \%$ and $91 \%$, respectively) $[25,38]$. The presence of three or one root canals was much lower in the three analysed groups. In the teeth collected from Radom three root canals appeared with the lowest frequency in comparison to other groups from Poland. One root canal was presented with a lower frequency in our study than in teeth from north-western Poland $(7 \%$ and $2 \%$, respectively) [25]. 
In first maxillary molars it is generally accepted that the most common form of this tooth has three roots and four root canals [12]. In each distobuccal and palatal root there is usually a single canal. However, the majority of the mesiobuccal roots have two canals, which is consistent with the broad buccolingual dimension of the mesiobuccal root and linked concavities on its mesial and distal surface. A second mesiobuccal canal (MB2) occurs commonly, with a frequency of 18-96\% [10]. In our study, the majority of the first maxillary molars have three roots $(91 \%)$, while $9 \%$ of teeth have two roots. The prevalence of occurrence of three roots was slightly lower than in the group from central Poland, where it reached $100 \%$. In these teeth, numbers of root canals ranged from three to four. Both in the group from Radom and in central Poland four root canals occurred in more cases ( $86 \%$ and $60 \%$, respectively). Additional canals (MB2) in the mesiobuccal roots were detected significantly more frequently in the teeth collected from Radom (86\%) than in the teeth from central Poland $(60 \%)$. The presence of three root canals in maxillary first molars was much lower in the Radom group (14\%) than in the comparative study (40\%) [32].

The mandibular first molar in typical two-rooted form contained either three or four canals. Most commonly, the mesial root contains two principle canals, in $60 \%$ of cases ending in two distinct apical foramina, and in $40 \%$ of cases end in one foramen. The distal root in two common canal configurations may contain a single kidney-shaped root canal or may contain two separate canals, the distobuccal (DB) and the distolingual (DL) $[1,4]$. However, according to some authors, four root canals may be also found in $25-29 \%$ of cases [8]. In our research, almost all the mandibular first molars have two roots. Three root canals occurred in $73 \%$ of teeth. With less frequency, four root canals appeared (22\%). In $5 \%$ of teeth there was a lack of one root (mesial or distal). Unfortunately, in this respect there are no modern data currently available from the region of Poland concerning diversity of root canals in mandibular first molars, whereas there are endodontic studies from areas geographically and ethnicity distant from Poland. However, comparison of our material with them may not result in reliable effects. For this reason, the gathered results from our study were compared with data concerning morphological diversity in first mandibular molars. Hess and Zurcher [17] reported that the prevalence of three root canals in mandibular permanent molar teeth was $78 \%$, whereas Skidmore and Bjorndahl [44] noted that the prevalence of four root canals is approximately $29 \%$ of first molars in the mandible. According to these studies, the predominant number of root canals in $18^{\text {th }}-19^{\text {th }}$ Radom teeth is similar to the usually occurring main root canal number noted in the literature (73 and $22 \%$, respectively).

Significant variability in root canal morphology between the population from Radom analysed in this study and contemporary populations from Poland has not been noticed. Despite the population inflow, this feature has not undergone significant modifications. It can be suspected, that due to short time distance between these groups and even migratory movements, variations in root canal systems did not change much. However, our assumptions should be checked based on genetic studies.

The canals in the root may reveal many variations in their configurations. According to this, various researchers proposed numerous classification systems based on the number and morphology of root canals in each type of tooth, depending on the teeth used in research and the group from which these teeth were obtained [16, 43, 52]. However, there is a lack of unity in the multiplicity of existing classification systems. Because our research is the first in bioarchaeological science to examine this issue and the existing classification systems were developed on modern dental material, we did not use any of them. So that the choice would not be accidental, we did not want to limit the gathered results to one classification. Moreover, one specific method of classification could not match our material. However, it seems that the morphological diversity of root canal systems from Radom was most similar to the Vertucci [52] classification. According to this classification, the incidence of type I canals in one-rooted maxillary premolars was $12 \%(2 / 17)$, type II was $29 \%(5 / 17)$, type IV was $53 \%$ (9/17) and type VII was $6 \%$ (1/17). In two-rooted maxillary premolars in buccal roots, mostly type I canal configurations occurred (91\%). All the palatal roots and three-rooted maxillary first premolars present type I canals. In two-rooted maxillary first molars, all the mesiobuccal roots present type II canal configurations, while fused roots (DB+PAL) present type IV canal configurations. From three-rooted maxillary first molars in the mesiobuccal root, the most common root canal configuration is type II (72\%). In distobuccal and palatal roots, type I canal configuration 
occurred in all cases. In mandibular first molars, the most common types of canal configurations were IV and II (59\% (32/54) and 39\% (21/54), respectively). The distal root was characterised mostly by type I root canal configurations (66\%). Three-rooted mandibular first molars depicted type I root canals.

According to the above data, teeth used in our study are similar to teeth from other Polish regions in terms of the most common number of roots and the most typical root canal numbers. The observed discrepancies are probably secondary to the degree of anatomical variation between the groups examined.

\section{CONCLUSIONS}

Knowledge about the variation of root canals is important not only from the point of view of endodontic treatment. It can also be interesting in studies of the population of past periods. The diversity of root canals may provide important information relating to the direction of migration and genetic relationships. In this respect, the analyses carried out show the similarity between the population of the $18^{\text {th }}-19^{\text {th }}$ century from Radom with other groups from modern Poland.

\section{Acknowledgements}

This work was supported by the National Science Centre (Poland) during the years 2013-2017 (Grant No. 2013/11/B/HS3/04117).

\section{REFERENCES}

1. Abella F, Patel $S$, Durán-Sindreu $F$, et al. Mandibular first molars with disto-lingual roots: review and clinical management. Int Endod J. 2012; 45(11): 963-978, doi: 10.1111/j.1365-2591.2012.02075.x, indexed in Pubmed: 22681628.

2. Agwan AS, Sheikh Z. Identification And Endodontic Treatment Of Threecanalled Maxillary First Premolar. J Ayub Med Coll Abbottabad. 2016; 28(3): 627-629, indexed in Pubmed: 28712254.

3. Ahmed HA, Abu-bakr NH, Yahia NA, et al. Root and canal morphology of permanent mandibular molars in a Sudanese population. Int Endod J. 2007; 40(10): 766-771, doi: 10.1111/j.1365-2591.2007.1283.x, indexed in Pubmed: 17714468.

4. Albuquerque DV, Kottoor J, Velmurugan N. A new anatomically based nomenclature for the roots and root canals-part 2: mandibular molars. Int J Dent. 2012; 2012: 814789, doi: 10.1155/2012/814789, indexed in Pubmed: 22505910

5. Al-Qudah AA, Awawdeh LA. Root and canal morphology of mandibular first and second molar teeth in a Jordanian population. Int Endod J. 2009; 42(9): 775-784, doi: 10.1111/j.1365-2591.2009.01578.x, indexed in Pubmed: 19549153.

6. Amardeep NS, Raghu S, Natanasabapathy V. Root canal morphology of permanent maxillary and mandibular canines in Indian population using cone beam comput- ed tomography. Anat Res Int. 2014; 2014: 731859, doi: 10.1155/2014/731859, indexed in Pubmed: 24895538.

7. Awawdeh L, Abdullah $\mathrm{H}, \mathrm{Al}-\mathrm{Qudah} \mathrm{A}$. Root form and canal morphology of Jordanian maxillary first premolars. J Endod. 2008; 34(8): 956-961, doi: 10.1016/j. joen.2008.04.013, indexed in Pubmed: 18634927.

8. Barańska-Gachowska M. Endodoncja wieku rozwojowego i dojrzałego. Czelej, Lublin 2004.

9. Baratto Filho F, Zaitter S, Haragushiku GA, et al. Analysis of the internal anatomy of maxillary first molars by using different methods. J Endod. 2009; 35(3): 337-342, doi: 10.1016/j.joen.2008.11.022, indexed in Pubmed: 19249591.

10. Buhrley $\amalg$, Barrows MJ, BeGole EA, et al. Effect of magnification on locating the MB2 canal in maxillary molars. J Endod. 2002; 28(4): 324-327, doi: 10.1097/00004770200204000-00016, indexed in Pubmed: 12043874.

11. Ceperuelo D, Lozano M, Duran-Sindreu F, et al. Root canal morphology of Chalcolithic and early bronze age human populations of El Mirador Cave (Sierra de Atapuerca, Spain). Anat Rec. 2014; 297(12): 2342-2348, doi: 10.1002/ ar.22958, indexed in Pubmed: 24943458.

12. Cleghorn BM, Christie WH, Dong CCS. Root and root canal morphology of the human permanent maxillary first molar: a literature review. J Endod. 2006; 32(9): 813-821, doi: 10.1016/j.joen.2006.04.014, indexed in Pubmed: 16934622.

13. Cleghorn BM, Christie WH, Dong CCS. The root and root canal morphology of the human mandibular second premolar: a literature review. J Endod. 2007; 33(9): 1031-1037, doi: 10.1016/j.joen.2007.03.020, indexed in Pubmed: 17931927.

14. Cucina A, Tiesler V, Wrobel G. Afinidades biológicas y dinámicas poblacionales mayas desde el Preclásico hasta el periodo Colonial. Los Investigadores de la Cultura Maya. 2005; 13: 559-567.

15. Gani OA, Boiero CF, Correa C, et al. Morphological changes related to age in mesial root canals of permanent mandibular first molars. Acta Odontol Latinoam. 2014; 27(3): 105-109, doi: 10.1590/S1852-48342014000300001, indexed in Pubmed: 25560687.

16. Gulabivala K, Opasanon A, Ng YL, et al. Root and canal morphology of Thai mandibular molars. Int Endod J. 2002; 35(1): 56-62, indexed in Pubmed: 11853239.

17. Hess W, Zurcher E. The Anatomy of Root Canals of the Teeth of the Permanent and Deciduous Dentition. William Wood \& Co, New York 1925

18. Huang YD, Wu J, Sheu RJ, et al. Evaluation of the root and root canal systems of mandibular first premolars in northern Taiwanese patients using cone-beam computed tomography. J Formos Med Assoc. 2015; 114(11): 1129-1134, doi: 10.1016/j.jfma.2014.05.008, indexed in Pubmed: 25174647.

19. Johnstone $M$, Parashos P. Endodontics and the ageing patient. Aust Dent J. 2015; 60: 20-27, doi: 10.1111/ adj.12281, indexed in Pubmed: 25762039.

20. Karunakaran JV, Samuel LS, Rishal Y, et al. Root Canal Configuration of Human Permanent Mandibular First Molars of an Indo-Dravidian Population Based in Southern India: An Study. J Pharm Bioallied Sci. 2017; 9(Suppl 1): S68-S72, doi: 10.4103/jpbs.JPBS_163_17, indexed in Pubmed: 29284938.

21. Kottoor J, Albuquerque DV, Velmurugan N. A new anatomically based nomenclature for the roots and root canals-part 1: maxillary molars. Int J Dent. 2012; 2012: 120565, doi: 10.1155/2012/120565, indexed in Pubmed: 22216031. 
22. Kottoor J, Albuquerque D, Velmurugan N, et al. Root anatomy and root canal configuration of human permanent mandibular premolars: a systematic review. Anat Res Int. 2013; 2013: 254250, doi: 10.1155/2013/254250, indexed in Pubmed: 24455268.

23. Lee JH, Kim KD, Lee JK, et al. Mesiobuccal root canal anatomy of Korean maxillary first and second molars by cone-beam computed tomography. Oral Surg Oral Med Oral Pathol Oral Radiol Endod. 2011; 111(6): 785-791, doi: 10.1016/j.tripleo.2010.11.026, indexed in Pubmed: 21439860

24. Lin YH, Lin HN, Chen CC, et al. Evaluation of the root and canal systems of maxillary molars in Taiwanese patients: A cone beam computed tomography study. Biomed J. 2017; 40(4): 232-238, doi: 10.1016/j.bj.2017.05.003, indexed in Pubmed: 28918912.

25. Lipski M, Woźniak K, tagocka R, et al. Root and canal morphology of the first human maxillary premolar. DAJ. 2005; 12(2-3).

26. Martins JNR, Ordinola-Zapata R, Marques D, et al. Differences in root canal system configuration in human permanent teeth within different age groups. Int Endod J. 2018; 51(8): 931-941, doi: 10.1111/iej.12896, indexed in Pubmed: 29363147.

27. Mirmohammadi $H$, Mahdi L, Partovi $P$, et al. Accuracy of cone-beam computed tomography in the Detection of a second mesiobuccal root canal in Endodontically treated teeth: an ex vivo study. J Endod. 2015; 41(10): 1678-1681, doi: 10.1016/j.joen.2015.06.011, indexed in Pubmed: 26282565.

28. Mohammadi Z, Shalavi S, Jafarzadeh H. Extra roots and root canals in premolar and molar teeth: review of an endodontic challenge. J Contemp Dent Pract. 2013; 14(5): 980-986, indexed in Pubmed: 24685809.

29. Naseri M, Safi Y, Baghban AA, et al. Survey of Anatomy and Root Canal Morphology of Maxillary First Molars Regarding Age and Gender in an Iranian Population Using Cone-Beam Computed Tomography. Iran Endod J. 2016; 11(4): 298-303, doi: 10.22037/iej.2016.8, indexed in Pubmed: 27790259.

30. Nosonowitz DM, Brenner MR. The major canals of the mesiobuccal root of the maxillary $1^{\text {st }}$ and $2^{\text {nd }}$ molars. NY J Dent. 1973; 43(1): 12-15, indexed in Pubmed: 4508675.

31. Nosrat A, Deschenes RJ, Tordik PA, et al. Middle mesial canals in mandibular molars: incidence and related factors. J Endod. 2015; 41(1): 28-32, doi: 10.1016/j. joen.2014.08.004, indexed in Pubmed: 25266468.

32. Olczak K, Pawlicka H. The morphology of maxillary first and second molars analyzed by cone-beam computed tomography in a polish population. BMC Med Imaging. 2017; 17(1): 68 , doi: $10.1186 / \mathrm{s} 12880-017-0243-3$, indexed in Pubmed: 29284426.

33. Peiris R. Root and canal morphology of human permanent teeth in a Sri Lankan and Japanese population. Anthropol Sci. 2008; 116(2): 123-133, doi: 10.1111/j.13652591.2008.01428.x.

34. Piątkowski S. Radom - zarys dziejów miasta. Wyd. Radom, Radom 2000.

35. Prado-Simón L, Martinón-Torres M, Baca P, et al. Three-dimensional evaluation of root canal morphology in lower second premolars of early and middle Pleistocene human populations from Atapuerca (Burgos, Spain). Am J Phys Anthropol. 2012; 147(3): 452-461, doi: 10.1002/ ajpa.22015, indexed in Pubmed: 22282075.

36. Ramírez-Salomón $M$, Vega-Lizama $E$, Tiesler $V$, et al. The C-shaped canal molar: an Endodontic-Archaeological study of the relationships between Mayan pre-Hispanic and contemporary population of Yucatán. Int Endod J. 2014; 47(11): 1084-1089, doi: 10.1111/iej.12255, indexed in Pubmed: 24471812.
37. R Development Core Team. R: A language and environment for statistical computing, R Foundation for Statistical Computing, Vienna: Austria 2013. http://www.R-project.org.

38. Rózyło TK, Miazek M, Rózyło-Kalinowska I, et al. Morphology of root canals in adult premolar teeth. Folia Morpholl. 2008; 67(4): 280-285, indexed in Pubmed: 19085869.

39. Saini T, Wilson CA. Taurodont molars: Review of literature and radiological features. Saudi Dent J. 1990; 2: 68-70.

40. Scott EC. Dental wear scoring technique. Am J Phys Anthropol. 1979; 51(2): 213-217, doi: 10.1002/ ajpa.1330510208.

41. Scott GR, Turner CG. The Anthropology of Modern Human teeth. Cambridge University Press, UK 1997.

42. Scott G, Dahlberg A. Microdifferentiation in tooth morphology among Indians of the American southwest. In: Kurten B (ed.). Teeth: form, function and evolution. Columbia University Press, New York 1982: 259-291.

43. Sert S, Sahinkesen G, Topçu FT, et al. Root canal configurations of third molar teeth. A comparison with first and second molars in the Turkish population. Aust Endod J. 2011; 37(3): 109-117, doi: 10.1111/j.1747-4477.2010.00254.x, indexed in Pubmed: 22117717.

44. Skidmore $A E$, Bjorndal AM. Root canal morphology of the human mandibular first molar. Oral Surg Oral Med Oral Pathol. 1971; 32(5): 778-784, doi: 10.1016/00304220(71)90304-5, indexed in Pubmed: 5286234.

45. Smith BH. Patterns of molar wear in hunger-gatherers and agriculturalists. Am J Phys Anthropol. 1984; 63(1): 39-56, doi: 10.1002/ajpa.1330630107, indexed in Pubmed: 6422767.

46. Studebaker B, Hollender L, Mancl L, et al. The incidence of second mesiobuccal canals located in maxillary molars with the aid of cone-beam computed tomography. J Endod. 2018; 44(4): 565-570, doi: 10.1016/j.joen.2017.08.026, indexed in Pubmed: 29153734.

47. Sulaiman AO, Dosumu OO, Amedari M. Maxillary first premolar with three root canals: a case report. Ann lb Postgrad Med. 2013; 11(2): 105-108, indexed in Pubmed: 25161429.

48. Thomas RP, Moule AJ, Bryant R. Root canal morphology of maxillary permanent first molar teeth at various ages. Int Endod J. 1993; 26(5): 257-267, indexed in Pubmed: 8300257.

49. Tian XM, Yang XW, Qian L, et al. Analysis of the root and canal morphologies in maxillary first and second molars in a chinese population using cone-beam computed tomography. J Endod. 2016; 42(5): 696-701, doi: 10.1016/j. joen.2016.01.017, indexed in Pubmed: 26994598.

50. Torres A, Jacobs R, Lambrechts $P$, et al. Characterization of mandibular molar root and canal morphology using cone beam computed tomography and its variability in Belgian and Chilean population samples. Imaging Sci Dent. 2015; 45(2): 95-101, doi: 10.5624/isd.2015.45.2.95, indexed in Pubmed: 26125004.

51. Turner CGI, Nichol CR, Scott Gr. Scoring procedures for key morphological traits of the permanent dentition: the Arizona State University dental anthropology system. In: Kelley MA, Larson CS (ed.). Advances in dental anthropology. Wiley-Liss, New York 1991.

52. Vertucci FJ. Root canal anatomy of the human permanent teeth. Oral Surg Oral Med Oral Pathol. 1984; 58(5): 589-599, doi: 10.1016/0030-4220(84)90085-9, indexed in Pubmed: 6595621

53. White TD, Folkens PA. The human bone manual. Academic Press, The Netherlands, Amsterdam 2005.

54. Zapłata R. Wstępne wyniki badań archeologicznych w wykopie 1/2010 na stanowisku 1 "Majdan" i w wykopie I-2/2010 na stanowisku 2 „Osada” w Radomiu. In: Buko A, Główka D, Trzeciecki M (ed.). Radom: korzenie miasta i regionu. Tom 2, Wyd. Instytutu Archeologii i Etnologii PAN, Warszawa 2011: 89-112. 